\title{
Smerter hos personer med psykisk \\ utviklingshemning
}

\section{Smertekartleggingsverktøyet MOBID-2 er beregnet på personer med demens. Det kan også fungere på personer med utviklingshemning, viser en pilotunders $\varnothing$ kelse.}

Stine Skorpen

Spesialsykepleier

Nasjonalt kompetansesenter for aldring og helse

Merethe Haugland

Vernepleier

Nedre Eiker kommune

Diana Pareli

Sykepleier og prosjektleder for implementering av MOBID-2

Nedre Eiker kommune

Smertekartleggingsskjema

Personer med utviklingshemning

Case

Sykepleien 2017105 (64151) (e-64151)

DOI: 10.4220/Sykepleiens.2017.64151

\section{Hovedbudskap}

Det finnes ikke gode nok smertekartleggingsskjemaer som er spesielt utviklet for voksne personer med utviklingshemning. Derfor har vi unders $\varnothing$ kt om kartleggingsverktøyet MOBID-2-smerteskala (Mobilisation-Observation-Behaviour-Intensity-Dementia), som er utviklet for personer med demens, kan benyttes på voksne personer med utviklingshemning. Resultatet viser at tjenesteyterne klarer å kartlegge smerter også hos denne målgruppen, men at fremgangsmåten bør endres noe. 
I dag er det flere personer med utviklingshemning som blir eldre enn for bare noen tiår siden (1). Voksne personer med utviklingshemning er mer utsatt for både fysiske og psykiske lidelser sammenliknet med befolkningen generelt. Hos noen starter dessuten aldringsprosessen opp tidlige enn forventet, og det kan gjøre dem mer sårbare for å utvikle aldersrelaterte sykdommer tidligere i livet (2-4).

\section{$\equiv$ «Personer med utviklingshemning ser ikke nødvendigvis sammenhengen mellom en fysisk skade på kroppen og smerten de føler.»}

Medfødte feilstillinger, ervervede lidelser og ofte usunne livsstilsvaner er risikofaktorer som kan medføre ulike smertetilstander $(2,5)$. Personer med utviklingshemning ser ikke nødvendigvis sammenhengen mellom en fysisk skade på kroppen og smerten de føler.

\section{Mindre smertestillende}

Samtidig har mange personer med utviklingshemning problemer med å kommunisere at de har vondt noe sted. De har også vansker med å be om hjelp på grunn av sin utviklingshemning (6).

Unders $\varnothing$ kelser fra inn- og utland viser at voksne og eldre personer med kognitiv svikt mottar mindre smertestillende medikamenter enn personer med adekvate kognitive funksjoner selv om mange lever med kroniske lidelser. Helsepersonell rapporterer at det er vanskelig å tolke de tvetydige signalene om smerter fra pasienter med demens eller fra personer med utviklingshemning $(6,7)$.

\section{Smertekartlegging}

Kartleggingsverkt øyet MOBID- 2 står for MobilisationObservation-Behaviour-Intensity-Dementia og ble utviklet for å kartlegge smerter hos personer med demens (7). MOBID-2 er ett av få smertekartleggingsskjemaer som baserer seg på observasjon og berøring, og ikke på muntlig eller skriftlig tilbakemelding fra pasienten.

I 2015 gjennomførte en prosjektgruppe i Nedre Eiker kommune en vellykket implementering av MOBID-2 på personer med demens i sykehjem og hjemmetjenesten i kommunen. I tillegg skulle de i 2016 implementere MOBID-2 i bofellesskap og i samlokaliserte boliger for voksne personer med utviklingshemning. 
Før de skulle iverksette implementeringen av MOBID-2, deltok vi i en pilotunders $\varnothing$ kelse der vi $\varnothing$ nsket å teste brukervennligheten til kartleggingsverktøyet på en gruppe voksne personer med utviklingshemning som bor i bofellesskap (se faktaboks). En slik unders $\varnothing$ kelse er ikke gjort før. På landsbasis er det 18564 personer med utviklingshemning over 16 år som har vedtak om tjenester etter helse- og omsorgsloven, og som bor i bofellesskap eller boliger med tilsyn (8).

\section{Prosjektdeltakere i pilotundersøkelsen av MOBID-2 på voksne personer med utviklingshemning}

- Ann Karin Johannesen, prosjektansvarlig for MOBID-2-implementering i Nedre Eiker kommune.

- Diana Pareli, sykepleier og prosjektleder for MOBID-2-implementering i Nedre Eiker kommune.

- Janne Gundersen, hjelpepleier og prosjektmedarbeider i MOBID-2implementeringen i Nedre Eiker kommune.

- Stine Skorpen, spesialsykepleier og fagkonsulent fra Nasjonal kompetansetjeneste for aldring og helse. Ansvar for Questback og skriftlig rapportering av pilotundersøkelsen.

- Merethe Haugland, vernepleier i Nedre Eiker kommune, prosjektdeltaker som bidro med casen i denne artikkelen.

\section{Prosjektet}

I forkant av pilotunders $\varnothing$ kelsen hadde prosjektgruppen et møte med virksomhetslederen og alle mellomlederne i bofellesskapene for å forankre prosjektet før oppstarten.

Vi valgte ut to middels store bofellesskap der det til sammen bor tretten voksne og eldre personer med utviklingshemning. Parallelt utviklet vi en spørreundersøkelse ved hjelp av Questback med sju spørsmål som skulle besvares etter at MOBID-2 var brukt. Vi sendte ut informasjon om unders $\varnothing$ kelsen til pårørende og verger og innhentet samtykke fra samtlige.

Før MOBID-2 tas i bruk, anbefales det å gjennomføre et standardisert opplæringsprogram for dem som skal ta skjemaet i bruk. Prosjektgruppen underviste og demonstrerte verkt øyet i forkant av pilotunders $\varnothing$ kelsen i begge boligene. 
Prosjektlederen sto for undervisningen, som var spesielt tilrettelagt for dem som jobber med personer med utviklingshemning. Undervisningen omhandlet smerte relatert til muskel- og skjelettsystemet, indre organer, hud og hode.

Tjenesteyterne fikk også lære om hvordan personer med utviklingshemning kan uttrykke smerte. De lærte også litt om smertestillende medikamenter og bruk av smerteintensitetsskala. Etter teoriundervisningen gjennomførte prosjektgruppen et rollespill der tjenesteyterne fikk prøve å fylle ut smerteskalaen etter å ha observert en unders $\varnothing$ kelse.

Etter undervisningen avtalte prosjektgruppen en tid for oppfølging. Da kom de tilbake til boligen og svarte på spørsmål om MOBID-2 og hjalp til med andre problemstillinger som hadde dukket opp underveis.

\section{MOBID-2-smerteskalaen}

Det anbefales at to personer som kjenner pasienten eller brukeren godt, skal utføre unders $\varnothing$ kelsen sammen. En skal utføre bevegelsene, mens den andre skal observere reaksjoner hos pasienten eller brukeren.

MOBID-2-skjemaet har to sider. På den første siden skal det registreres smerteatferd og smerteintensitet mens pasienten eller brukeren blir ledet gjennom fem øvelser:

- åpne begge hender

- strekke armene mot hodet

- bøye og strekke ankler, knær og hofte

- snu seg i sengen

- sette seg opp på sengekanten

På side to av skjemaet skal det kartlegges smerteatferd relatert til følgende:

- hode, munn og hals

- bryst, lunge og hjerte

- Øvre del av mage

- bekken, nedre del av mage

- hud, infeksjon, sår 


\section{Kroppsskisse}

En kroppsskisse på skjemaet skal gjøre det lettere å fokusere på alle lokalisasjoner for den enkelte. Den som utfører unders $\varnothing$ kelsen, skal vurdere og sette skår på en smerteintensitetsskala og krysse av for hva vedkommende observerer av ansiktsuttrykk eller verbale ytringer. Den som unders $\varnothing$ ker, skal aldri spørre om pasienten eller brukeren har vondt mens vedkommende holder på med undersøkelsen.

Til sist skal den som har utført unders $\varnothing$ kelsen og gjort observasjoner, gi en helhetlig vurdering av pasientens eller brukerens smerte. Ved skår over 3 skal tiltak iverksettes. Tiltak kan være at pasienten eller brukeren får smertestillende medikamenter.

I forkant kan smertestillende medikament være ordinert «ved behov» i pasientens eller brukerens pasientjournal. Hvis det ikke er bestemt hva vedkommende kan få, må lege kontaktes. Lege må også kontaktes hvis pasienten har smerter som trenger annen smertelindring.

\section{Spørreundersøkelsen}

Questback-skjemaet ble sendt via e-post til 16 tjenesteytere, og resultatet ble en svarprosent på 81 .

I det første spørsmålet spurte vi om de har lært mye nytt om smerter og smerteatferd etter å ha deltatt i undervisningen. 53,8 prosent svarte at de hadde lært mye nytt, mens 46,2 prosent svarte at de kunne det meste fra før. I denne unders $\varnothing$ kelsen visste vi ikke noe om respondentenes utdanningsnivå, men vi tror at majoriteten er utdannet som helsefagarbeidere.

\section{Lett å bruke skjemaet}

Det neste spørsmålet dreide seg om hvorvidt skjemaet var intuitivt og enkelt å bruke. «Ja», svarte 84,6 prosent, og «nei», svarte kun 15,4 prosent. Det kom inn to kommentarer til spørsmålet. Den ene kommenterte at «det er vanskelig å gå inn to stykker på rommet for å observere». Den andre kommenterte at «brukergruppen ikke passer inn». 
De to kommentarene er ikke så lette å tolke, da de er svært korte og uten forklaring på henholdsvis hva som gjør det vanskelig med å være to observatører, og hvorfor brukergruppen ikke passer inn. Men hvis vi sammenlikner med kommentarene fra de andre spørsmålene under, så mener de trolig at noen beboere ikke tolererer endringer av rutiner. Hvis det alltid pleier å komme én person $\mathrm{i}$ morgenstellet, kan det føles utrygt hvis det kommer to.

Kommentar nummer dreide seg om at brukergruppen ikke passer til å bruke skjemaet. Begge kommentarene handler vel egentlig ikke om skjemaet, men om det å få til undersøkelsen.

\section{Motstand mot øvelsene}

Spørsmål nummer tre handlet om hvordan det gikk å utføre unders $\varnothing$ kelsene. Det var kun tolv personer som svarte på dette spørsmålet, mot 13 som besvarte de andre spørsmålene. 58,3 prosent svarte at det gikk fint å utføre unders $\varnothing$ kelsene. 41,7 prosent svarte at det var vanskelig.

Til dette spørsmålet fulgte det med fem kommentarer. En kommentar lød at «dette er brukere som har så faste rutiner og har mye motstand mot endringer. I tillegg liker de ikke å få beskjed om hva de skal gjøre».

En annen skrev at «brukerne motsetter seg å gjøre øvelsene, men vi gjennomførte det likevel uten forklaring på hva vi holdt på med eller uten å oppfordre til samarbeid. Observerte heller under stell, og fikk utført noen av фvelsene likevel».

\section{Vare for endringer}

To andre kommentar lød som følger: «Brukerne nektet å samarbeide» og «brukeren ville ikke, prøvde flere ganger». Til sist var det en som sa: «Vi er ikke vant til å bruke det, det kreves mer implementering hos hele personalgruppen hvis dette skal anvendes.»

Vi vurderer og tolker det siste sitatet som at vedkommende syntes at personalgruppen hadde fătt for lite forklaring, opplæring og oppfølging i hvordan og hvorfor de skulle bruke MOBID-2. Det virker også som om tjenesteyterne ikke hadde fătt god nok informasjon om at det er lov å være kreativ og tenke utradisjonelt når de vil lete etter smerter og benytte skjemaet. 
«Vi vet at mange personer med utviklingshemning er mer vare og sårbare for endringer i rutiner enn mange andre.»

Fremgangsmåten, med en som observerer og en som berører personen som skal unders $\varnothing$ kes, vil kanskje ikke fungere like godt til målgruppen personer med utviklingshemning.

Vi vet at mange personer med utviklingshemning er mer vare og sårbare for endringer i rutiner enn mange andre. Derfor er det litt opp til primærkontaktene å finne ut den best tenkelige måten å få utført unders $\varnothing$ kelsen på for hver især. Men det var over halvparten, nesten 60 prosent, som hadde svart at det gikk greit å utføre unders $\varnothing$ kelsen, og hadde ingen kommentarer til det.

\section{Mangler språk for smerte}

Spørsmål fire spurte informanten om det var vanskelig å vurdere og tolke smerteintensitet, og ba vedkommende fylle ut resultatet på skalaen. 61,5 prosent av informantene svarte at de syntes det var vanskelig å vurdere smerteintensitet og fylle ut skjemaet. 38,5 prosent syntes det var enkelt. Til dette spørsmålet lå det ved åtte kommentarer fra informantene.

Flere av kommentarene handlet om at brukeren ikke har språk, slik at det er vanskelig å kommunisere med dem, og dermed vanskelig for tjenesteyterne å vite om de tolker riktig på skalaen: « ... fordi brukeren noen ganger ikke kan beskrive sin egen opplevelse av smerter». Denne kommentaren tyder på at vedkommende ikke hadde fått god nok informasjon om at skjemaet er beregnet nettopp på dem som ikke kan gjøre rede for seg muntlig.

En annen skrev at «noen av brukerne skjuler smerten». Dette utsagnet er en subjektiv tolkning av en annen persons følelser. En annen kommentar som derimot ga mening, var følgende: «Det er ikke lett å tolke ansiktsuttrykk bestandig.» Det er vi enige i, og den kommentaren sammenfaller med følgende utsagn: «Det er individuelle forskjeller, og man bør kjenne pasienter uten språk veldig godt.» 


\section{Viktig å kjenne brukeren}

En annen sa at «brukeren har ikke språk, og det er vanskelig å se om han har smerter, vi merker det på fargen i ansiktet og humøret hans». Denne kommentaren illustrerer godt hvor viktig det er at det er personalet, som kjenner personen meget godt, som skal gjøre unders $\varnothing$ kelsen. De er de eneste som er kompetente nok til å fylle ut på skalaen. Hvis de er usikre, kan de prøve igjen dagen etter.

Til sist var det en som kommenterte at «det kan være vanskelig fordi noen brukere vil kunne uttrykke at det gjør vondt, uansett smerte eller ikke». Den siste kommentaren kan vi også tolke som at vedkommende ikke hadde fått god nok opplæring i at skjemaet baserer seg på observasjon og ikke på muntlige tilbakemeldinger.

Det var cirka 60 prosent som syntes det var vanskelig å fylle ut riktig på smerteskalaen. Dette resultatet sammenfaller med liknende spørreunders $\varnothing$ kelser blant dem som jobber med personer med demens.

Prosjektgruppen har fra før implementert MOBID-2 i sykehjem og hjemmetjenesten i Nedre Eiker kommune. De fant ut at erfarne MOBID-2-brukere sier at det går lettere når de har blitt trygge på å benytte skjemaet.

\section{MOBID-2 var nyttig}

Videre spurte vi om de avdekket smerteatferd hos personen de unders $\varnothing$ kte og observerte. 61,5 prosent avdekket smerteatferd, mens 38,5 prosent ikke fant noen smerter. Det lå ikke ved noen kommentarer til dette spørsmålet. Svaret viser bare at de avdekket smerte og nyanserer ikke rundt graden av smerte eller hvorvidt de fikk smertestillende medikamenter i etterkant.

Vi spurte om MOBID-2 ville være et nyttig verktøy for dem som tjenesteytere fremover. På dette spørsmålet svarte 84,6 prosent at verktøyet ville være nyttig for dem fremover. 15,4 prosent svarte at det ikke ville være nyttig. Til dette spørsmålet lå det ved to kommentarer. En sa at «det er vanskelig å benytte MOBID-2 med vår brukergruppe».

\section{Trenger mer opplæring}


Den andre kommenterte følgende: «Det er allerede fokus på at ved atferdsendring skal det somatiske sjekkes ut først. Jeg vil ikke si at det ikke er et nyttig verktøy, men det må implementeres bedre i personalgruppen først hvis det skal bli anvendt, tenker jeg». Den siste kommentaren er en viktig tilbakemelding.

\section{$\equiv \ll 92,3$ prosent svarte at de ville anbefale MOBID-2 til andre kollegaer.»}

Tjenesteyterne må få bedre opplæring i og oppfølging av hvordan de bruker skjemaet. For å få til en vellykket implementering av MOBID- 2 bør lederne involvere seg mer i implementeringsprosessen.

Det siste spørsmålet dreide seg om hvorvidt de ville anbefale MOBID-2 til andre kollegaer. 92,3 prosent svarte at de ville anbefale MOBID-2 til andre kollegaer. 7,7 prosent, det vil si én respondent, sa at vedkommende ikke ville anbefale å bruke dette skjemaet til målgruppen voksne personer med utviklingshemning.

\section{Case}

Før vi oppsummerer, Ønsker vi å ta med en historie fra en vernepleier som kan illustrere hvor viktig det kan være å kartlegge smerter systematisk hos personer som ikke selv kan si ifra om hva som plager dem.

Denne historien handler om en mann på snart 60 år. Han er født med et sjeldent syndrom der det er vanlig med misdannelser i kraniet, syns- og hørselsskader, trange luftveier og stive ledd, spesielt i knær og albuer. Etter først å ha bodd noen år i en større institusjon har han bodd i et bofellesskap de siste 25 årene.

Han er svært stiv i knærne og kan ikke bevege kneleddet. Han har ofte en utfordrende atferd. I tillegg vandrer han mye rundt med støtte av rullator, både når han er på dagtilbud og hjemme i bofellesskapet. Det er ikke uvanlig at han går i åtte timer eller mer per døgn.

Han har språk, men gjentar ofte ting. Han kan stille det samme spørsmålet veldig mange ganger i løpet av kort tid. Han har også en innlært atferd der han sier at enhver berøring er smertefull, spesielt i stellesituasjoner. Da kan smerteutrop komme uavhengig av berøringen. 
På kveldstid klager han mye over hodepine, uavhengig av om han har fått smertestillende. I tillegg har han et unormalt søvnmønster, der han har hatt en tendens til å stå opp i femtiden på morgenen.

\section{Fastlegen ga paracetamol}

Under en konsultasjon hos fastlegen tok tjenesteyteren som ledsaget brukeren til kontroll, opp smertelindring på vegne av brukeren. På spørsmål fra legen svarte brukeren selv at han ikke hadde smerter. Brukerens svar samsvarer ikke med personalets observasjoner om at han tidvis er tydelig smertepåvirket. Svaret samsvarer heller ikke med kunnskap om hvordan stive ledd og misdannelser ofte medføre smerter.

Fastlegen bestemte at brukeren kunne starte med paracetamol, 1 gram x 3. Tjenesteyteren påpekte til legen at paracetamol har liten eller ingen effekt på smerter i muskulatur og ledd. Fastlegen fastholdt at det var paracetamol eller ingenting han ville ordinere, da brukeren tidligere har respondert dårlig på smertebehandling.

\section{Kartlegging}

Primærkontakten utførte den første MOBID-2-kartleggingen av brukeren rett etter at hun hadde fått opplæring av prosjektgruppen i hvordan skjemaet skulle brukes. Den første testen hun utførte på brukeren, var å bøye foten hans litt opp for å få på ham sko. Den bevegelsen førte til at hun observerte unnvikelsesatferd med spark av ben, smertelyder og tydelige grimaser.

I utgangspunktet hadde primærkontakten en formening om at brukeren hadde smerter spesielt i området rundt knærne. Han hadde ikke tidligere vist noen spesielle tegn til smerter i anklene, men ved første kartlegging og senere kartlegginger registrerte primærkontakten smerter i begge anklene.

På grunn av oppstartsvansker med registreringene utførte primærkontakten kartlegginger over tre uker. Resultatet av kartleggingene viste at han hadde smerter til tross for at han hadde fått paracetamol tre ganger daglig. Primærkontakten bestilte ny time hos fastlegen for brukeren. Hun viste fastlegen resultatene fra MOBID-2-kartleggingen og spurte på vegne av brukeren om han kunne fă tilbud om et smerteplaster i stedet for flere tabletter. 


\section{Bedre med smerteplaster}

Fra bofellesskapet har de gode erfaringer med å bruke smerteplaster på andre beboere fordi det gir jevn smertelindring gjennom hele døgnet. Fastlegen skrev ut en kur på Norspan-depotplaster, 5 mikrogram for fire uker. Fastlegen $\varnothing$ nsket at primærkontakten skulle gjennomføre en ny kartlegging av smerte etter at brukeren hadde begynt med depotplasteret.

En uke etter oppstarten med smerteplaster foretok primærkontakten en ny kartlegging med MOBID-2 på brukeren og fikk nye resultater. Bevegelser som tidlige ga utslag og viste smerter, gikk nå å gjennomføre uten at hun kunne se tegn til smerter hos brukeren. Brukeren hadde også endret $\varsigma \varnothing v n m \varnothing$ nster og sov bedre om natten enn tidligere.

Primærkontakten fortsatte å kartlegge med MOBID-2 i to uker etter at smertebehandlingen startet. Lederen $\mathrm{i}$ bofellesskapet formidlet resultatene av kartleggingen til fastlegen, og i dag får brukeren paracetamol, 1 gram x 3 og Norspan-depotplaster, 5 mikrogram per døgn. Han har fătt godkjent smerteplaster på blå resept.

\section{Oppsummering}

Ut fra svarene i spørreunders $\varnothing$ kelsen sier tjenesteyterne at skjemaet er intuitivt og enkelt å bruke. De synes det er vanskelig å gjennomføre undersøkelsene på de beboerne som er vare for endringer i rutiner og skeptiske til nye ting. Etter denne pilotunders $\varnothing$ kelsen har vi vurdert ulike endringer som bør gjennomføres av fremtidige brukere av MOBID-2.

\section{三 «Det er vanskelig å gjennomføre undersøkelsene på de beboerne som er vare for endringer i rutiner og skeptiske til nye ting.»}

De som skal gjennomføre teoriundervisning i forkant, må tydelig informere dem som skal utføre kartleggingen om at de må være kreative og løsningsorienterte når målgruppen er personer med utviklingshemning. Da kan vi ikke alltid benytte den fremgangsmåten som opprinnelig ble prøvd ut på personer med demens, der det var to fra personalet til stede under kartleggingen. 


\section{Veien videre}

Denne pilotunders $\varnothing$ kelsen er for liten til å gi noe svar, men den har gitt oss noen tendenser. I løpet av høsten 2017 skal et fagmiljø på Hamar teste ut MOBID-2 i regi av prosjektet

«Kompetanseheving i lindrende omsorg og behandling innenfor tjenester til personer med utviklingshemming». De skal benytte kvalitative intervjuer for å evaluere skjemaet.

De fleste deltakerne i pilotundersøkelsen syntes det var vanskelig å tolke smerter og registrere intensiteten på smerteskalaen, men tjenesteyterne i Nedre Eiker kommune klarte det.

MOBID-2 fungerer for å avdekke smerter hos voksne personer med utviklingshemning. De som har benyttet kartleggingsskjemaet, mener at det er «det beste vi har på markedet for tiden».

Prosjektgruppen mener at er det et godt verktøy, men fremgangsmåten $b \varnothing r$ endres noe for at det skal bli tilrettelagt for personer med utviklingshemning. Vi håper at MOBID-2 skal testes ut i større skala for å gi oss mer vitenskapelige svar på sikt.

\section{Tips for å ta i bruk MOBID-2}

Vi har laget en liste med forslag som kan være til hjelp for dere som vil ta i bruk MOBID-2-skjemaet.

- Innføring og bruk av MOBID-2 må forankres godt i ledelsen før oppstart.

- Spesialtrent helsepersonell skal undervise og drive opplæring av MOBID2. Alle ansatte må få opplæring i små grupper. Det er viktig med oppfølging én uke etter første gangs opplæring.

- En «superbruker» bør få ekstra opplæring og avsatt arbeidstid for å følge opp og dokumentere kartlegging med MOBID-2 i bofellesskap.

- MOBID-2-skjemaet må bare benyttes av personell som kjenner beboeren som skal kartlegges, meget godt.

- Fastleger må informeres om at dere skal i gang med å benytte MOBID-2. Det er en god investering å få til et godt samarbeid med legene fra oppstarten av.

- I tillegg til å kartlegge og lindre smerte til en person med utviklingshemning bør dere samtidig kartlegge miljøet vedkommende lever i, for å finne ut hva som eventuelt fører til smerte og hvilke strukturelle tiltak som bør endres eller igangsettes.

Forslagene er basert på erfaringer etter en pilotunders $\varnothing$ kelse av hvor brukervennlig smertekartleggingsskjemaet MOBID-2 er på voksne personer med utviklingshemning. 


\section{Referanser}

1. Sandberg M, Ahlström G, Kristensson J. Patterns of somatic diagnoses in older people with intellectual disability: A Swedish eleven year case-control study of inpatient data. J Appl Res Intellect Disabil. 2015;30(1):157-71.

2. Nasjonalt kompetansemiljø om utviklingshemning. Helseoppfølging av personer med utviklingshemning. Trondheim: NAKU; 2007. Tilgjengelig fra: http://naku.no/sites/default/files/Helserapport_o.pdf (nedlastet 02.11.2017).

3. Davis R, Proulx R, van Schrojenstein Lantman-de Valk $\mathrm{H}$. Health issues for people with intellectual disabilities: the evidence base. I: Taggart L, Cousins W, red. Health promotion for people with intellectual and developmental disabilities. Berkshire, England: Open University Press; 2014 (s. 7-16).

4. Scott HM, Havercamp S. Systematic review of health promotion programs focused on behavioral changes for people with intellectual disability. J Intellect Disabil Res. 2016;54(1):63-76.

5. NOU 2016:17. På lik linje. Åtte løft for å realisere grunnleggende rettigheter for personer med utviklingshemming. Oslo: Departementenes servicesenter; 2016.

6. Findlay L, Williams AC, Scior K. Exploring experiences and understandings of pain in adults with intellectual disabilities. J Intellect Disabil Res. 2014;58(4):358-67.

7. Huseb $\varnothing$ B. Smerteevaluering ved demens. Tidsskrift for Den norske legeforening. 2009;129:1996-8.

8. Helsedirektoratet. Personer med utviklingshemmings bruk av fylkeskommunale og kommunale helse- og omsorgstjenester. Oslo: Helsedirektoratet; 2017. Rapport IS2555 . 